\title{
THE EFFECT OF ASSERTIVE COMMUNITY TREATMENT TOWARDS ANXIETY AND DEPRESSION ON BREAST CANCER CLIENT
}

\author{
Andikawati Fitriasari ${ }^{1 *}$, Ahmad Yusuf ${ }^{2}$, Ririn Probowati ${ }^{3}$ \\ ${ }^{1}$ Faculty of Nursing and Midwifery, Nahdlatul Ulama University, Surabaya, East Java, Indonesia \\ ${ }^{2}$ Faculty of Nursing, Airlangga University, Surabaya, East Java, Indonesia \\ ${ }^{3}$ Nursing Program, College of Health of Jombang Regency Government, Jombang, East Java, \\ Indonesia \\ *Correspondence: \\ Andikawati Fitriasari \\ Email: andikawati_f@unusa.ac.id \\ Address: Faculty of Nursing and Midwifery, Nahdlatul Ulama University, Surabaya, Jl. SMEA No. 57 \\ Surabaya, East Java, Indonesia
}

\begin{abstract}
Background: Breast cancer increases the occurrence of psychosocial problems, namely anxiety and depression. Anxiety and depression have shown an effect on the quality of life. Assertive Community Treatment is a psychosocial service that involves the family's role in overcoming breast cancer client anxiety and depression.

Objective: This study aimed to determine the effect of Assertive Community Treatment towards anxiety and depression of breast cancer clients.

Method: The research design used was quasi-experiment with a pre-posttest control group design. This research subject determines by using purposive sampling. The study population was breast cancer clients who seek treatment at Public Health Center of Medokan Ayu in Surabaya. The sample is breast cancer clients who have inclusion criteria a) age 30-60 years old, b) live with her partner, c) has chronic pain \pm 1-5 years. The instrument is PDQBC (Psychosocial Distress Questionnaire Breast Cancer subscales anxiety and depression. Data analysis used paired T-Test and Independent T-Test.

Result: Paired T test results showed anxiety values in the treatment group $p=0.000$, depression value $p=0.001$. The results of the independent $\mathrm{T}$ test statistic obtained $p$ value $=0.000$ showed a significant difference between anxiety and depression of breast cancer clients in the control group and the treatment group.

Conclusion: Assertive Community Treatment provides a good impact in order to reduce the level of anxiety and depression in clients with breast cancer. Assertive Community Treatment (ACT) is recommended to be given by teams.
\end{abstract}

Key words: Assertive Community Treatment, Anxiety, Depression, Breast Cancer Clients, Palliative.

\section{INTRODUCTION}

Breast cancer is a non-infectious disease, which until now has become a concern health problem. Breast cancer happened in both women and men, especially at the age of $30-50$ years.
Women who have the disease, especially cancers related to reproductive organs, can increase the risk of psychosocial problems. Psychosocial problems of people with breast cancer in the psychiatric field include anxiety, and depression can even lead to 
pathological distress (Anindita, Raymondalexas, \& Suryo, 2010). Fear arises when a woman is first diagnosed with breast cancer and continues during the treatment process. Their partners and anxiety will leave thoughts about death trigger this anxiety; changes in body image, fear cannot play a role as a whole woman.

Women with breast cancer also feel feelings of depression. Feelings of depression are manifest as feelings of worthless and helpless in carrying out daily activities. Depression is one of the most common psychiatric problems experienced by women with breast cancer (Chang, Lai, $\mathrm{Hu}$, \& Chin-hung, 2017). In many cases, depression cause of the effects of treatment, such as already in the menopause phase, lack of family support, which can cause further consequences such as sleep disturbances.

Psychosocial problems experienced by women with breast cancer, if not immediately addressed, can have a significant effect on the decreased quality of life, prognosis of healing in breast cancer patients, reduced sensitivity of treatment efficacy, decreased metabolism (Sukma, 2018). Family and social support are need by women with breast cancer (Chang et al., 2017). Based on research, that women with breast cancer who get support from the family especially husband can reduce anxiety and depression (Chang et al., 2017). Management of psychosocial problems, specifically to deal with anxiety and depression, can be implemented through Assertive Community Treatment (ACT).

Assertive Community Treatment (ACT) is a community mental health treatment model for people with mental illness who developed by Stein and Test. ACT model was a holistic approach to services women with breast cancer who have depression and anxiety, helping with illness management, medication management, and anything else critical to an individual's community adjustment. ACT services aim to help sufferers to be able to live in the community by building relationships and support by families, husbands, and children ((Peter, Ostergaard, Nordentoft, \& Hounsgaard, 2019). Characteristics of Assertive Community Treatment (ACT) strengthen the motivation of sufferers in undergoing treatment ((Vijverberg, Ferdinand, Beekman, \& Meijel, 2017). In addition, modified ACT services for breast cancer clients experiencing anxiety and depression. The implementation of Assertive Community Treatment (ACT) by nurses by involving families, in this case, husband/spouse and children. The nurse builds an approaching relationship with clients and families regarding breast cancer care. The implementation of Assertive Community Treatment (ACT) is a focus on recovery, shared decision making, strengths-based treatment planning and use of generic community resources. Based on the background above, this study aims to explain the Assertive Community Treatment (ACT) to cope anxiety and depressed client breast cancer.

\section{METHODS}

Study Design

The design of this study was a quasiexperiment with a pre-posttest control group design.

\section{Setting}

This research was conducted at the Public Health Center of Medokan Ayu Surabaya. Public Health Center of Medokan Ayu is one of the public health centers that have palliative care. The study was done on February until March 2017.

\section{Research Subject}

The population in this study were cancer clients seeking treatment at the Public Health Center of Medokan Ayu Surabaya. The total population of breast cancer clients seeking treatment at the Public Health Center of Medokan Ayu Surabaya was 30 people $(\mathrm{N}=30$ people $)$ 
who met the inclusion criteria: 1) 30-60 years old, 2) woman who have a husband/spouse live together, 3) woman with long period of breast cancer $\pm 1-5$ years. The research subjects were taken randomly according to the sample size formula of 30 respondents. The research subjects were then divided into two random groups: 15 respondents entered the treatment group (got Assertive Community Treatment) and 15 respondents entered the control group (receive health education like usual). The distribution of samples in both groups was determined randomly.

\section{Instruments}

The instrument of this study used PDQBC (Psychosocial Distress Questionnaire Breast Cancer), a screening instrument specific for the patients with breast cancer. The PDQ-BC subscales are trait anxiety, depressions, body image, physics, social, sexual, financial. For this research take subscales anxiety and depression.

\section{Data Analysis}

The data that has been collected is then processed using Paired $T$ Test dan Independent $\mathrm{T}$ Test. Statistical tests were performed using the SPSS program.

\section{Ethical Consideration}

This research has gone obtained permission from Ethics Comission Faculty of Nursing of Airlangga University with license number: 356-KEPK which do at Public Health Center of Medokan Ayu, Surabaya.

\section{RESULTS}

Characteristic of Respondents

Table 1. Distribution of Frequency of Respondents in the Public Health Center of Medokan Ayu, Surabaya on February until March $2017(\mathrm{n}=30)$.

\begin{tabular}{|c|c|c|}
\hline $\begin{array}{c}\begin{array}{c}\text { Characteristics of } \\
\text { Respondents }\end{array} \\
\end{array}$ & $\begin{array}{l}\text { Frequency } \\
\text { (n) }\end{array}$ & $\begin{array}{c}\text { Percentage } \\
(\%)\end{array}$ \\
\hline \multicolumn{3}{|l|}{ Age } \\
\hline 40-50 years & 13 & 43.3 \\
\hline 51-60 years & 17 & 56.7 \\
\hline Total & 30 & 100.0 \\
\hline \multicolumn{3}{|l|}{ Educational Level } \\
\hline Elementary School & 2 & 6.7 \\
\hline Junior High School & 13 & 43.3 \\
\hline Senior High School & 13 & 43.3 \\
\hline College/ University & 2 & 6.7 \\
\hline Total & 30 & 100.0 \\
\hline \multicolumn{3}{|l|}{ Occupational } \\
\hline Working & 9 & 30.0 \\
\hline Not Working & 21 & 70.0 \\
\hline Total & 30 & 100.0 \\
\hline \multicolumn{3}{|l|}{ Period of Sick } \\
\hline 1-2 years & 18 & 60.0 \\
\hline 3-5 years & 12 & 40.0 \\
\hline Total & 30 & 100.0 \\
\hline \multicolumn{3}{|l|}{ Treatment } \\
\hline Surgery + Chemotherapy & 6 & 20.0 \\
\hline Surgery + Radiotherapy & 10 & 33.3 \\
\hline $\begin{array}{l}\text { Surgery + Chemotherapy } \\
+ \text { Radiotherapy }\end{array}$ & 14 & 46.7 \\
\hline Total & 30 & 100.0 \\
\hline
\end{tabular}

Source: Primary data of questionnaire, 2017

Based on the results of the study above, it was found that the majority of respondents aged 51-60 years were 17 respondents (56.7\%). Most respondents' education was junior high school and senior high school, which together amounted to 13 respondents $(43.3 \%)$. Most respondents also did not work as many as 21 respondents $(70.0 \%)$. The respondents who had suffered from breast cancer for 1-2 years were 18 respondents $(60.0 \%)$. For the treatment received by them, the most is surgery + chemotherapy + radiotherapy as many as 14 respondents $(46.7 \%)$ 
Determine the Effect of Assertive Community Treatment towards Anxiety and Depression on Breast Cancer Clients in the Public Health Center of Medokan Ayu, Surabaya on February until March 2017 by using Paired T Test and Independent T Test

Table 2. Examination of the Effect of Assertive Community Treatment towards Anxiety on Breast Cancer Clients in the Public Health Center of Medokan Ayu, Surabaya on February until March 2017 by using Paired T Test and Independent $\mathrm{T}$ Test $(\mathrm{n}=30)$.

\begin{tabular}{lllll}
\hline \multicolumn{1}{c}{ Variables } & n & Mean & SD & $\boldsymbol{p}$-value \\
\hline Paired T Test & & & & \\
\hline $\begin{array}{l}\text { Treatment Group } \\
\text { Pretest }\end{array}$ & 15 & 31.27 & 9.239 & 0.000 \\
$\quad$ Posttest & 15 & 18.80 & 3.840 & \\
$\quad$ Control Group & & & & \\
$\quad$ Pretest & 15 & 20.93 & 3.150 & 0.732 \\
$\quad$ Posttest & 15 & 21.40 & 4.405 & \\
\hline Independent T Test & & & & \\
\hline$\quad$ Treatment Group & 15 & -12.47 & 9.620 & 0.000 \\
$\quad$ Control Group & 15 & 0.47 & 5.181 & \\
\hline$\quad$ Source: Primary data of questionnaire, 2017
\end{tabular}

The mean value of anxiety in the treatment group after the intervention was $18.80(\mathrm{SD}=3.840)$. From the Paired T-test results obtained $p=0.000$, which means there is a significant difference in anxiety before and after the intervention.

The mean anxiety value is 20.93 and the average anxiety value in the control group research respondents after 21.40 posttest and Paired T-test results $p=0.732$ which shows no difference in anxiety before and after the intervention.

Statistical test results of the treatment and control group anxiety with Independent T-test obtained $p$-value $=0.000$ showed a significant difference in breast cancer client anxiety between the control group and the treatment that received ACT.
Table 3. Examination of the Effect of Assertive Community Treatment towards Depression on Breast Cancer Clients in the Public Health Center of Medokan Ayu, Surabaya on February until March 2017 by using Paired $\mathrm{T}$ Test and Independent $\mathrm{T}$ Test $(\mathrm{n}=30)$.

\begin{tabular}{lcccc}
\hline \multicolumn{1}{c}{ Variables } & n & Mean & SD & $\boldsymbol{p}$-value \\
\hline Paired T Test & & & & \\
\hline Treatment Group & & & & \\
Pretest & 15 & 23.87 & 8.323 & 0.001 \\
Posttest & 15 & 15.27 & 3.081 & \\
Control Group & & & & \\
Pretest & 15 & 18.67 & 3.848 & 0.689 \\
Posttest & 15 & 19.00 & 4.551 & \\
\hline Independent T Test & \multicolumn{4}{l}{} \\
\hline$\quad$ Treatment Group & 15 & -8.60 & 7.679 & 0.000 \\
$\quad$ Control Group & 15 & 0.33 & 3.155 & \\
\hline & Source: Primary data of questionnaire, 2017 \\
\end{tabular}

The mean value of depression in the treatment group after the intervention was 15.27 ( $\mathrm{SD}=3.081)$. From the Paired T-test results obtained $p=0.001$ which means there are significant differences in depression before and after the intervention.

The mean value of depression in the control group study respondents after posttest 19.00 and the results of the Paired T-test were $p=0.689$ which showed no difference in depression before and after the intervention. The results of the depression test of the treatment and control group with Independent $\mathrm{T}$-test showed that the value of $p=0.000$ showed a significant difference in the depression of breast cancer clients between the control group and the treatment group that received assertive community treatment.

\section{DISCUSSION}

Psychosocial problems experienced by women with breast cancer are anxiety and depression since being diagnosed until undergoing treatment (Aly, Eilateef, \& Mohamed, 2017). Anxiety experienced is triggered while waiting for the results of examinations, undergoing a series of treatments (chemotherapy, surgery, radiotherapy), fears of not being able to 
carry out the role properly as a mother or wife, financial fears that will have an impact on medical expenses. The type of work affects the level of anxiety experienced by respondents who are, on average, housewife, who are very dependent on their husband's income.

In this study, most respondents experienced a change in role in their family. Some respondents felt that as a wife and housewife they could not perform their functions optimally due to their weak and quickly tiring conditions. Respondents who, before being sick, were active in community activities, after being diagnosed and undergoing breast cancer treatment, preferred to stay at home and not leave the house. This is because respondents feel afraid when joining the community, will be seen differently and feel sorry for the circumstances experienced. Depressed clients will make negative feedback on themselves so they will tend to remember negative information. In accordance (Pratiwi, 2017). This is in line with research conducted by Oetami, et al (2014) that breast cancer patients undergoing treatment express the perceived anxiety that is worrying about the effects of the treatment they are undergoing so they cannot carry out daily activities as before (Oetami, Thaha, \& Wahiduddin, 2014).

Depression experienced in the form of emotional and physical reactions. Emotional reactions that are felt are feelings of sadness, hopelessness, feeling useless in carrying out the role of both wife and mother. The physical reaction experienced in the form of the body feels pain, feels tired easily, can't sleep well, loses appetite. Depression in clients with breast cancer is not only due to the degree/classification of breast cancer but also the impact of the treatment they are undergoing. Singh et al., 2012 stated that depression experienced by clients with breast cancer can aggravate physical symptoms and can reduce adherence in undergoing treatment.
Decreased adherence to undergoing treatment is due to clients with breast cancer losing motivation. Loss of motivation for breast cancer women is one form of psychological disturbance. The implementation of ACT in overcoming depression in clients with breast cancer is by providing an explanation or information related to causes, prognosis, treatment strategies. Researchers direct negative thoughts that cause emotional disturbances into positive thoughts that can increase motivation in undergoing treatment. Distortion of the mind will produce negative thoughts. Individuals who experience cognitive distortion will experience negative expectations about the environment, themselves and the future. According to the Kortjik research (2010), the implementation of ACT can improve psychosocial and motivation in medicine (Kortrijk, Staring, Van Baars, \& Mulder, 2010). In ACT, researchers motivate clients to develop positive aspects they have so that they turn negative thoughts into realistic perceptions. Realistic, positive thinking will generate positive feelings so negative thoughts can be controlled.

The implementation of ACT involves families, both husband and children. The role of the husband provides full support to his partner in any form. Support in the form of emotional, information, instrumental and appreciation. Researchers provide an explanation to the family regarding understanding, causes, prognosis and treatment of breast cancer clients. Providing information to the family can provide a feeling of security, comfort to breast cancer clients. Clients of breast cancer feel welcome, appreciated so that they foster a sense of optimism in undergoing treatment. Accordance with the research that has been done, stating the role of family and those around him to provide life support for people living with breast cancer, will be of enormous significance. The family must take care so that the patient 
does not experience stress and then reduce anxiety and depression.

This research has limitations in implementing ACT. ACT is a multidisciplinary service, but in this study only conducted by psychiatric nurses. ACT should be carried out for a long time because it fosters closeness with clients and family. This study only carried out within one month.

\section{CONCLUSION}

Assertive Community Treatment (ACT) can reduce anxiety and depression in people with breast cancer. Implementation of Assertive Community Treatment (ACT) involves the support of the family. Family support is important things to increase quality of life clients with breast cancer.

\section{SUGGESTIONS}

Future research, Assertive Community Treatment (ACT) is recommended to be given by teams include psychologist, doctor, nutrition's to get maximum results in improving the quality of life clients with breast cancer.

\section{ACKNOWLEDGMENT}

We are thank you to all participants, and Public Health Center of Medokan Ayu, Surabaya where the research did.

\section{DECLARATION OF CONFLICTING INTEREST}

None.

\section{FUNDING}

This study used the researchers' personal funds.

\section{AUTHOR CONTRIBUTION}

Andikawati Fitriasari: As a main researcher.

Ahmad Yusuf: As a supervisor.

Ririn Probowati: As a supervisor

\section{ORCID}

Andikawati Fitriasari

https://orcid.org/0000-0002-5801-8807/

Ahmad Yusuf

https://orcid.org/0000-0002-6669-0767/

Ririn Probowati

None.

\section{REFERENCES}

Aly, H. Y., Eilateef, A. A. E. A., \& Mohamed, A. E. S. (2017). Depression and anxiety among females with breast cancer in sohag university: results of an interview study. Remedy Open, 2(1080), 1-7.

Anindita, Y. P. C., Raymondalexas, M. C., \& Suryo, P. Y. (2010). Hubungan antara Pemberian Radioterapi dengan Terjadinya Distress , Anxiety dan Depresi pada Penderita Kanker Payudara. Berita Kedokteran Masyarakat, 26(1), 1-6. https://doi.org/10.1007/978-3-31912817-7

Chang, C., Lai, C., Hu, P., \& Chin-hung, V. (2017). Depression and family support in breast cancer patients. 2389-2396.

Kortrijk, H. E., Staring, A. B. P., Van Baars, A. W. B., \& Mulder, C. L. (2010). Involuntary admission may support treatment outcome and motivation in patients receiving assertive community treatment. Social Psychiatry and Psychiatric Epidemiology, 45(2), 245-252. https://doi.org/10.1007/s00127-0090061-1

Oetami, F., Thaha, ida leida, \& Wahiduddin. (2014). Psychological Impact of Breast Cancer Treatment in Hospital Dr. Wahidin Sudirohusodo Makassar. Analisis Dampak Psikologis Pengobatan Kanker Payudara Di Rs Dr. Wahidin Sudirohusodo Kota Makassar.

Pasaribu, J. (2012). PENGARUH TERAPI Kognitif Dan Terapi Penghentian 
Pikiran Terhadap Perubahan Ansietas, Depresi Dan Kemampuan Mengontrol Pikiran Negatif Klien Kanker Di Rs Kanker Dharmais Jakarta. Universitas Indonesia.

Penzenstadler, L., \& Anci, E. (2019). Effect of Assertive Community Treatment for Patients with Substance Use Disorder: A Systematic Review. 5667. https://doi.org/10.1159/000496742

Persons, J. B., \& Therapy, C. B. (2017). Anxiety and depression change together during treatment. (July).

Peter, J., Østergaard, B., Nordentoft, M., \& Hounsgaard, L. (2019). Cognitive adaptation training combined with assertive community treatment: A randomised longitudinal trial. Schizophrenia Research, 135(1-3), 105-111.

https://doi.org/10.1016/j.schres.2011. 12.014

Pratiwi, S. R., Widianti, E., \& Solehati, T. (2017.). Gambaran Faktor-Faktor yang Berhubungan dengan Kecemasan Pasien Kanker Payudara dalam Menjalani Kemoterapi. 167174.

Singh ThingbaijamB, and Singh, Laishram. (2012). Breast cancer and depression : issues in clinical care. Medical journal of Indonesia. Volume 21 : 240-246.

Sukma, D. M. (2018). Digital Digital Repository Repository Universitas Universitas Jember Jember Digital Digital Repository Repository Universitas Universitas Jember Jember. Universitas Jember.

Vijverberg, R., Ferdinand, R., Beekman, A., \& Meijel, B. Van. (2017). The effect of youth assertive community treatment: a systematic PRISMA review. 1-18. https://doi.org/10.1186/s12888-0171446-4
Cite This Article As: Fitriasari, A., Yusuf, A., \& Probowati, R. The Effect of Assertive Community Treatment towards Anxiety and Depression on Breast Cancer Client. Nurse and Health: Jurnal Keperawatan 2019; 8(2): 153159. 